\title{
CORPORATION AS THE ACTORS OF FISHERIES CRIME IN INDONESIA ${ }^{\Omega}$
}

\author{
Sri Dwi Retno Ningsih, ${ }^{1}$ Supanto ${ }^{2}$ and Emmy Latifah ${ }^{2}$ \\ ${ }^{1}$ Postgraduate of Law Study Program, Faculty of Law University of Sebelas Maret, Surakarta - Indonesia \\ Email: sridwiretnoningsihlimbong@gmail.com \\ ${ }^{2}$ Faculty of Law University of Sebelas Maret, Surakarta - Indonesia
}

\begin{abstract}
In Indonesia, the corporation is already recognized as one of the perpetrators of criminal acts in a variety of specific criminal acts and regulations, including in the Fisheries Act. Article 1 paragraph 14 Law Number 31 Year 2004 jo Law Number 45 Year 2009 concerning Fisheries, states that every person is a person, the individual or Corporation. This research is normative juridical research. The approach used is statute approach. Data analysis techniques using the deductive approach of law and interpretation. The results showed that in the theory of criminal law, there is some form of the position of the Corporation as the perpetrator of a criminal offence may be subject to liability. The purpose of this study is to examine how the legal position of the Corporation as the perpetrator of the criminal offence of fishing in Indonesia.
\end{abstract}

Keywords: corporations, criminal act, fisheries

\begin{abstract}
Abstrak
Di Indonesia, korporasi sudah diakui sebagai salah satu pelaku tindak pidana di berbagai peraturan perundang-undangan tindak pidana khusus, termasuk dalam Undang-undang Perikanan. Pasal 1 ayat (14) Undang-Undang Nomor 31 Tahun 2004 jo Undang-Undang Nomor 45 tahun 2009 tentang perikanan menyatakan bahwa setiap orang adalah orang perseorangan atau Korporasi. Istilah korporasi diartikan sebagai kumpulan orang dan/atau kekayaan yang terorganisasi baik merupakan badan hukum maupun bukan badan hukum. Penelitian ini adalah penelitian yuridis normatif. Pendekatan yang digunakan adalah pendekatan perundang-undangan (statute approach). Teknik analisis data menggunakan penafsiran hukum dan pendekatan deduktif. Hasil penelitian menunjukkan bahwa dalam teori hukum pidana terdapat beberapa bentuk kedudukan korporasi sebagai pelaku tindak pidana yang dapat dikenakan pertanggungjawaban. Tujuan penelitian ini adalah untuk mengkaji bagaimana kedudukan hukum korporasi sebagai pelaku tindak pidana perikanan di Indonesia.
\end{abstract}

Kata kunci: korporasi, tindak pidana, perikanan

\section{Introduction}

In Indonesia there are three areas of sea that are very vulnerable of illegal fishing, namely: Arafuru sea, Natuna Sea, and North Sulawesi Sea. Vulnerability of these territorial waters caused of illegal fishing activities can not be separated from the large potential of fishery contained in it. This can be known from the Decree of the Minister of Marine Affairs and Fisheries of the Republic of Indonesia Number 45 Year 2011 concerning Estimating the Potential of Fish Resources In WPP-RI (Fisheries Management Teritory-Republic of Indonesia) stated that the seas in WPP 711 (Karimata waters, Natuna Sea and South China Sea) have the largest potential of fish resources, about 1,059 tons per year. ${ }^{1}$

Data from the Ministry of Marine Affairs and Fisheries 2018 showed that the number of illegal fishing cases occurred in Indonesia in 2015 is 198 cases, 237 cases in 2016, and 193 cases in 2017. The number of illegal fishing cases by corporations in 2015 is 11 cases, 22 cases in 2016, and 24 cases in 2017. This data indi-

$\Omega \quad$ This article was a part of Thesis research entitled "Penegakan Hukum Terhadap Korporasi yang Melakukan Tindak Pidana Illegal, Unregulated and Unreported Fishing (IUU-FISHING) Di Provinsi Riau” Program Pascasarjana Universitas Sebelas Maret.

Bob Ivan, "Illegal Fishing di Kawasan Perairan Kepulauan Bangka Belitung (Studi Kasus Penangkapan Ikan Tanpa Dokumen yang Sesuai)", Jurnal Kriminologi Indonesia, Vol. 10 No. 2, November 2014, p. 41-42, 
cates that the corporation is one of the perpetrators in a fishery crime. Ministry of Marine Affairs and Fisheries as a major leading sector in the management and utilization of marine and fishery resources has taken firm policy to remove illegal fishing. ${ }^{2}$

Corporations in Indonesia are legal subjects that can be punished. It is regulated in Article 1 paragraph (14 and 15) of Law Number 31 Year 2004 in conjunction with Law Number 45 Year 2009 concerning fisheries (then called as the Fisheries Act). However, there is still uncertainty about when and in what positions the corporation may be subject to criminal sanctions. Several judgments of criminal sanctions are often imposed on individuals only. ${ }^{3}$ This is because the procedures for examining corporations as perpetrators of criminal acts are still unclear including in the fishery sector.

According to Fisse and Braithwaite, there are twenty important points to consider in realizing fair and effective law enforcement for corporate crime. Three important things are: first, the allocation of liability for corporate crime must be based on the understanding that corporate action is not only the amount of the individuals actions within the corporation, but also the action of the corporation itself. Second, the allocation of liability for a corporate crime must be able to allocate the liability to every responsible person, individual, sub-unit of the corporation, corporation, parent company, industrial association, or those who supervise the corporation such as an accountant or even a regulator. Third, the allocation of liability to the individual must be able to avoid the possibility of sacrificing certain parties in the corporation which was sacrificed. ${ }^{4}$ Based on the background above, the problem studied in this

Chairun Nasirin, Dedy Hermawan, "Kontrovesi Implementasi Kebijakan Penenggelaman Kapal dalam Rangka Pemberantasan Illegal Fishing", Spirit Publik, Vol. 12. No. 1, April 2017, p. 10

3 Decision of Rokan Hilir District Court Number 231/Pid. B/2008/PN.RHL

4 Andri G. Wibisana, "Kejahatan Lingkungan oleh Korporasi: Mencari Bentuk Pertanggungjawaban Korporasi dan Pemimpin/Pengurus Korporasi untuk Kejahatan Lingkungan di Indonesia", Jurnal Hukum dan Pembangunan, Vol. 46, No. 2, 2016, p. 150 paper is about how the law position of corporate as a fishery crime perpetrator in Indonesia.

\section{Research Methods}

This research is normative juridical research. The approach used is the statute approach. The data used are secondary data, including primary legal materials, secondary legal materials, and tertiary legal materials related to the study of corporations as perpetrators of fishery crime. The techniques of data collection use literature study, then data analysis techniques use legal interpretation.

\section{Discussion}

\section{Principle of Corporation as Law Subject}

Corporation is one of body as the result of legal structure. The created body consisted of the corpus, the physical structure and in its body, the law incorporates elements of the animus that makes the body has a personality In Indonesia. ${ }^{5}$ Meanwhile, the subject of law is anything that can have the right and obligation to act in law. ${ }^{6}$ The legal subject consists of 2 (two) individuals and legal entities. ${ }^{7}$

Reviewed from the historical aspect, corporate recognition as a subject of crime in criminal law has been in place since 1635 when the British legal system recognizes that corporations can be criminally liable for minor crimes. The United States recognized its existence in 1909 through a court decision. After United States, the Netherlands, Italy, France, Canada, Australia, Switzerland and some European countries followed the trend, including Indonesia. ${ }^{8}$ In the Netherlands, firmly accepted the corporation as the subject of the offense since 1 September 1976 set forth in the common crime law (commune strafrecht) and has also de-

Satjipto Raharjo, 2000, Ilmu Hukum, Bandung: Citra Aditya Bakti, p.69

6 Amirullah, "Korporasi Dalam Perspektif Subyek Hukum Pidana", Al-Daulah, Vol 2 No. 2, Oktober 2012, p. 145 Ibid

8 Levina Yustianingtyas, "Pertanggungjawaban Pidana Korporasi dalam Tindak Pelanggaran HAM di Indonesia", Jurnal Ilmu Hukum NOVELTY, Vol. 7 No. 1 Februari 2016, p. 28 
termined who should be responsible for the criminal acts committed by the corporation. ${ }^{9}$

The subject of corporate criminal law in Indonesia is known since $1951 .{ }^{10}$ There are several laws that recognize about a corporation may be declared as a subject of criminal law. The regulation includes Law Number 41 Year 1999 concerning Forestry, Article 78 Paragraph (14); Law Number 32 Year 2009 concerning Environmental Protection and Management, Article 116 paragraph (1) and (2), Article 117, and Article 119; Law Number 31 Year 1999 concerning the Eradication of Corruption jo Law Number 20 Year 2001, Article 2 paragraph (1) and Article 3; Law Number 8 Year 2010 concerning concerning Prevention of the Crime of Money Laundering, Article 6 paragraph (1) and (2), and Article 7, 8 and 9; The Law on Economic Crimes (Article 15), and so on. ${ }^{11}$ The law is a special regulation outside the Criminal Code that provides for corporate criminal liability in order that corporations may be held accountable for their misdeeds. ${ }^{12}$

I.S. Susanto, stated corporations have five important characters generally: ${ }^{13}$ first, it is a subject of artificial law that has special legal standing; second, has a limited life span; third, to gain power (from the state) to conduct certain business activities; fourth, owned by shareholders; and fifth, the shareholder's liability for corporate loss is usually limited to the number of shares it owns.

The perpetrator of a criminal offense is a legal subject because his actions can be held criminally liable. The subject of the law itself is a supporter of rights and obligations that can be either person or legal entity. In the begin-

9 Hariman Satria, "Pertanggungjawaban Pidana Korporasi dalam Tindak Pidana Sumber Daya Alam", Jurnal Mimbar Hukum, Vol. 28 No. 2, July 2016, p. 294

10 Yudi Krismen, "Pertanggungjawaban Pidana Korporasi dalam Kehahatan Ekonomi", Jurnal Ilmu Hukum, Vol. 4, No. 1, 2014, p.11.

11 Jegesson P. Situmorang, "Pertanggungjawaban Pidana Korporasi dalam Menanggulangi Tindak Pidana Perikanan”, Diponegoro Law Journal, Vol. 5, No. 3, 2016, p. 4

12 Rully Trie Prasetyo, "Tindak Pidana Korporasi dalam Perspektif Kebijakan Formulasi Hukum Pidana", Jurnal Hukum Khaira Ummah, Vol. 12. No. 4 December 2017, p. 3

13 I.S. Susanto, 1995, Kejahatan Korporasi, Semarang: Badan Penerbit Universitas Diponegoro, p. 83 ning, The perpetrator of the crime was only human, then developed into human and legal entity.

In relation to the perpetrators of criminal acts in the field of fisheries, Article 84 to Article $100 \mathrm{C}$ of the Fisheries Law, stated that the offender is "everyone". Article 1, paragraph 14, which "every person" means an individual or a corporation. Further, Article 1 paragraph 15 states that a corporation is an organized collection of people and/or assets whether it is a legal entity or non-legal entity. The existing fisheries law will become a guide in law enforcement either by law enforcers or by other authorities. ${ }^{14}$

\section{Concept of Fishery Crime}

There are 2 (two) qualifications of criminal acts in the field of fisheries regulated in Law Number 31 Year 2004 jo. Law Number 45 Year 2009 concerning Fisheries, namely: first, crime offenses (misdrijven); and second, a violation offense (overtredigen). The offense of crime is all acts of the offender contrary to the interests of the law, while the offense of violation is all acts that do not obey the prohibition or obligation determined by the state authorities $^{15}$. Criminal offenses in the field of fisheries including crime offenses are provided for in $\mathrm{Ar}$ ticle 84, Article 85, Article 86, Article 88, Article 91, Article 92, Article 94, Article 100A and Article 100B. The offense of violation is regulated in Articles 87, 89, 90, 95, 96, 97, 98, 99, 100 and $100 \mathrm{C} .{ }^{16}$

Criminal acts in the field of fisheries conducted corporation criminal targets only addressed to the board alone, while the corporation cannot be sentenced. This arrangements will cause many weaknesses. Imposing sanction of imprisonment or fine "only" to the corporate management only and it causes injustice. On the other side, the imposition of a criminal to

14 Maria Maya Lestari, "Penegakan Hukum Pidana Perikanan Di Indonesia Studi Kasus Pengadilan Negeri Medan”, Jurnal Ilmu Hukum, Vol 3 No 2, Year 2013, p. 3

15 Gatot Supramono, 2011, Hukum Acara Pidana dan Hukum Pidana Di Bidang Perikanan, Jakarta: Rineka Cipta, p. 153

16 Ibid. 
corporate executives is also not enough to guarantee that the corporation became immune to criminal sanctions and would have an impact on the repetition of his actions later on. ${ }^{17}$

Law Number 31 Year 2004 Jo. Law Number 45 Year 2009 concerning Fisheries included in laws within the scope of administrative law. This is proved by Article 26 paragraph (1) of this Law which states that: "Everyone who undertakes a fishing business in the field of capture, cultivation, transportation, processing and marketing of fish in the fishery management area of the Republic of Indonesia shall have Fishery Business Permit". Furthermore, Article 26 paragraph (2) states that: "The obligation of having Fishery Business Permit as referred to in paragraph (1) not applicable to small fishermen and/or small fish farmers". Article 27 paragraph (1) states that: "Any person owning and/or operating an Indonesian flagged fishing boat used for fishing in the fishery management territory of the Republic of Indonesia and/or the open seas shall have Fishing Permit. Article 27 paragraph (2) states that: "Any person owning and/or operating a foreign-flag fishing boat used for fishing in the fishery management territory of the Republic of Indonesia shall have Fishing Permit. Furthermore, Article 28 Paragraph (1) states that: "Every person owning and/or operating a fishing boat in the territory of fisheries management of the Republic of Indonesia shall have License of Fishing Boat. Although this law has set out how the licensing process should be adhered to by the fishery business actor, however, there is still a violation of the provisions. In the framework of strengthening and compliance with the provisions of such an administrative nature, in Law Number 45 Year 2009 jo Law Number 31 Year 2004 concerning Fisheries contains a criminal threat which is a policy in penal law

Corporate crime has a wide impact. This crime is done in a structured and systematic manner. Not only affects the state's finances, but also violates the socio-economic rights of large society. The General Director of Marine

17 Ibid. and Fishery Resources Supervision of the Ministry of Marine Affairs and Fisheries examines state losses due to fishery crime, each year Indonesia is estimated to suffer a loss of IDR 101,040 trillion/year. This not only made Indonesia suffered losses in the form of state revenues but also economic losses, ecological losses, and social losses. Economic losses, among others, the Government lost the economic value of stolen fish, missing of Fishery Products Charges, subsidized fuel. ${ }^{18}$

\section{The Position of Corporate as Perpetrator of Fishery Crime}

The presence of a corporation is like a double-edged knife. On the other hand, corporation have important roles in pushing the economic growth of a country and even the world, but on the other side the corporation becomes the mastermind behind the crime. ${ }^{19}$ In the theory of criminal law, there are several forms of corporate status as perpetrators of criminal acts which may be responsible: first, corporate management as perpetrators of criminal and criminally responsible board; second, corporations as perpetrators of criminal offenses and corporate officers who are criminally responsible; third, corporations as perpetrators of criminal acts as well as criminally responsible parties; and fourth, the management of the corporation as a perpetrator of criminal acts and at the same time is criminally responsible. ${ }^{20}$

The acceptance of corporations as perpetrators of criminal acts, the problem related to the corporate responsible criminally is arised, that is whether the corporation can have errors, either in the form of intent or negligence. This is a problem because in practice it is very difficult to determine whether or not there is a mistake in the corporation.

18 Ferdy Ari Saputra, “Dampak Program Pemberantasan IUU Fishing Terhadap Hubungan Bilateral Indonesia-China, eJournal Ilmu Hubungan Internasional, Vol. 4, No. 4, 2016, p. 1272

19 Hariman Satria, "Pertanggungjawaban Pidana Korporasi dalam Tindak Pidana Sumber Daya Alam", Jurnal Mimbar Hukum, Vol. 28. No. 2, 2016, p. 289

20 Fatchur Rohman, "Sistem Pertanggungjawaban Pidana Korporasi", May 19 $19^{\text {th }} 2016$. https://constituendum. word-press.com/2016/05/19/sistem-pertanggungjawaban-pidana-korporasi, accessed on Februari $19^{\text {th }} 2018$ 
Related to the liability of corporations, there is a principle stated that mistakes do not apply absolutely. In this case, corporate criminal liability refers to the doctrine of "strict liability" and "vicarious liability" which in principle is a deviation from the principle of mistake. The similarities and differences of "strict liability" and "vicarious liability" lie on both do not require "mens rea" or an element of mistakes in the person charged with the criminal. The difference between them lies on the "strict liability crimes". The lability is directly to the perpetrators, while the "vicarious liability" of criminal liability is indirect. In United Kingdom also known as the principle of identification, where corporate liability is equated with the individuals respnsibility. In this identification principle, "mens rea" is not excluded likes the case "strict liability" and "vicarious liability". The principle of identification is one of the principles that justifies corporate liability in criminal law. This principle stated that the act or the will of the director is also an act or will of the corporation (the act and state of mind of the person are the acts and state of mind of the corporation). ${ }^{21}$

There are several exceptions to the equalization of corporate responsibilities with private individuals. The exceptions are: first, in cases which naturaly cannot be done by corporation, for example rape and perjury; and second, in criminal cases which may not be imposed on the corporation of imprisonment or death penalty. ${ }^{22}$

An unlawful act with an element of mistake done by a corporation may be subject to criminal liability, since the corporation is a legal entity having the same rights and duties as humans. The specific provisions of the legislation are based on the legal principle of lex specialis derograt lex generalis which means that the law of a special character defeats or over-

21 Richard Card in Hanafi Amrani, "Reformasi Pertanggungjawaban Pidana", Jurnal lus Quia lustum. Vol 6, No 11,1999, p. 29

22 Dwidja Priyatno, "Reorientasi dan Formulasi Sistem Pertanggungjawaban Pidana Korporasi dalam Kebijakan Kriminal dan Kebijakan Hukum Pidana", Syiar Hukum, Vol. 9 No. 3, 2007, p. 206 rides the general law. However, in practice, it is rare for Judges to decide a criminal case involving corporations as their liability. The main reason is because the formulation of the article that regulates the corporation is still bias so the Judge only asks the liability to the human. ${ }^{23}$

In relation to fisheries, Law Number 31 Year 2004 Jo. Law Number 45 Year 2009 concerning Fisheries regulates that a fishery crime is committed by a corporation, its penal sanctions are imposed on its committee, and the criminal sanction is increased by one-third of the imposed penalty. Criminal sanctions imposed on the offenders of fishing crimes are appropriate with Articles 84, 85, 86, 87, 88, 89, 90, 91, 92, 93, 94, 94A, 95, Article 96, Article 97, Article 98, Article 99, and Article 100.

Based on many alternative punishments that can be imposed on corporations in order to achieve the purpose of alternatives criminal punishment to other sanctions that may be imposed on corporations, such as follows: ${ }^{24}$ first, sanctions are worth the money (monetary sanction). The monetary sanction are: (a) Replacing the economic benefits (recoups any economical benefit) that is obtained as a result of crime; (b) Replace all or part of the cost of investigation and reparition of any losses incurred; (c) Fines. Second, additional criminal in the form of: (a) Prohibition of acts or activities that cause the continuation or recurrence of the crime; (b) Property asset and proceeds of crime by providing protection for the rights of a bona fide third party; (c) Issuing or disqualifying a convicted person or corporation from a government contract, fiscal profit or subsidy; (d) ordering the dismissal of the manager and disqualifying or canceling the officer of his/her position; (e) ordering the publication of facts relating to a court decision; (f) requiring the convict to comply with the conditions established by the court to prevent the prisoner from repeating his or her actions; (g) Order the con-

\footnotetext{
23 Pujiati, "Pertanggungjawaban Pidana Korporasi dalam Tindak Pidana Pelayaran", Jurnal Kajian Hukum dan Keadilan IUS, Vol. IV, No. 1 April 2016, p.26

24 Dwidja Priyatno, op.cit.
} 
vict to notify the persons who have been harmed by his actions; ( $h$ ) order a convicted person (if an organization) to notify the public in all the countries where the organization operates, as to its branches, to its directors, officers, managers, employees, related to the liability or sanctions imposed on them; (i) Order the convicted person to perform a service or community service; (j) Orders to terminate or discontinue the activities (temporarily or permanently) revocation of activity permits, dissolution of business ventures. ${ }^{25}$

Losses due to criminal acts committed by corporations are as follows: ${ }^{26}$ first, fuel subsidies are enjoyed by unauthorized ships; second, reduction of Non-Tax State Revenue; third, Indonesian (local) fishing opportunities are reduced, since illegal boats are foreign ships that use foreign ships crew; fourth, the threat to the sustainability of fish resources due to the catch is not being detected, either type, size or quantity; fifth, the catch is generally taken directly abroad (the country of origin of the ship) resulting in the loss of some of the country's foreign exchange and reduced opportunities for added value from the processing industry; sixth, economic losses in the form of fishery retribution paid at Indonesian shipping rates; and seventh, stolen fish production (volume and value).

Timbo stated, that criminalization of corporations provides a deterrent effect to corporations and characterizes the strength of law enforcement in a country. ${ }^{27}$ Therefore, in order to maintain national wealth in the form of fishery resources would require government action in maintaining natural resources. Law is very important media as the control and prevention of actions that can disrupt the stability of the management and preservation of fish resources and the environment. Law Number 31 Year

25 Yuniarti Dwi Pratiwi, “Pertanggungjawaban Pidana Illegal Fishing Korporasi dalam Cita-Cita Indonesia Poros Maritim Dunia", Jurnal Defendonesia, Vol. 1 No. 2, Juni 2016, p. 5

26 Nunung Mahmudah, op cit., p. 97

27 Timbo Mangaranap Sirait, "The Implementation of Procedural Law of Liability Enforcement of Corporate Crime In Integral Criminal Justice System", Jurnal Dinamika Hukum, Vol. 17, No. 3, 2017, P. 347.
2004 jo. Law Number 45 Year 2009 concerning Fisheries provides clarity and legal certainty to law enforcement of criminal acts in the field of fisheries, which includes investigation, prosecution and examination in court. ${ }^{28}$

\section{Conclusion}

There are several laws that recognize that a corporation is declared a subject of criminal law, namely: Law Number 41 Year 1999 concerning Forestry, Law Number 32 Year 2009 concerning the Protection and Management of the Environment, Law Number 31 Year 1999 concerning the Eradication of Corruption, Law Number 8 Year 2010 concerning Prevention of the Crime of Money Laundering. Meanwhile, corporate crime in the fishery sector is regulated in Law Number 31 Year 2004 Jo Law Number 45 Year 2009 concerning Fisheries. The criminal act of the fishery is done by the corporation and the criminal sanction is imposed on the committee, and the criminal penalty is added by one third of the imposed penalty. In this case there are two kinds of sanctions as an alternative to punishment, namely: sanctions worth of money (monetary sanction) and additional sanction.

\section{Suggestion}

The need for alternative criminal penalties against corporations if criminal sanctions in article 84 to article 100 of the Fisheries Act are ineffective. Alternative sanctions that can provide a deterrent effect and the achievement of the purpose of punishment is deprivation of company assets that can be used for the public interest.

\section{References}

Amirullah. "Korporasi dalam Perspektif Subyek Hukum Pidana". Al- Daulah. Vol 2 No. 2, October 2012. Pp. 139-160. DOI: https:// doi.org/10.15642/ad.2012.2.2.139-160;

28 Yuli Winiari Wahyuningtyas, “Penanganan Tindak Pidana di Bidang Perikanan Berdasarkan Peraturan Perundang-Undangan Di Indonesia”, Jurnal Rechtens, Vol. 6, No. 1, Juni 2017, p 34 
Amrani, Hanafi. "Reformasi Pertanggungjawaban Pidana". Jurnal lus Quia lustum. No. 11 Vol. 6 1999. Pp. 26-43;

Ivan, Bob. "Illegal Fishing di Kawasan Perairan Kepulauan Bangka Belitung (Studi Kasus Penangkapan Ikan Tanpa Dokumen yang Sesuai). Jurnal Kriminologi Indonesia. Vol. 10 No. 2. November 2014. Pp. 41-48;

Krismen, Yudi. "Pertanggungjawaban Pidana Korporasi dalam Kehahatan Ekonomi". Jurnal Ilmu Hukum. Vol. 4. No. 1, 2014. Pp. 133-159;

Lestari, Maria Maya "Penegakan Hukum Pidana Perikanan Di Indonesia Studi Kasus Pengadilan Negeri Medan". Jurnal Ilmu Hukum. Vol. 3 No. 2, 2013. Pp. 271-295;

Mahmudah, Nunung. 2015. Illegal Fishing: Pertanggunjawaban Pidana Korporasi di Wilayah Perairan Indonesia. Jakarta: Sinar Grafika;

Nasirin, Chairun \& Hermawan, Dedy. "Kontrovesi Implementasi Kebijakan Penenggelaman Kapal dalam Rangka Pemberantasan Illegal Fishing". Spirit Publik. Vol. 12. No. 1. April 2017. Pp. 9-24;

Prasetyo, Rully Trie. "Tindak Pidana Korporasi dalam Perspektif Kebijakan Formulasi Hukum Pidana". Jurnal Hukum Khaira Ummah. Vol. 12. No. 4 December 2017. Pp: 727-741;

Pratiwi, Yuniarti Dwi. "Pertanggungjawaban Pidana Illegal Fishing Korporasi Dalam Cita-Cita Indonesia Poros Maritim Dunia". Jurnal Defendonesia, Vol. 1 No. 2, June 2016. Pp. 66-72;

Priyatno, Dwidja. "Reorientasi dan Formulasi Sistem Pertanggungjawaban Pidana Korporasi dalam Kebijakan Kriminal dan Kebijakan Hukum Pidana". Syiar Hukum. Vol. 9 No. 3. 2007. Pp. 202-217;

Pujiati. "Pertanggungjawaban Pidana Korporasi Dalam Tindak Pidana Pelayaran". Jurnal Kajian Hukum dan Keadilan IUS. Vol. IV, No. 1 April 2016. Pp. 24-43. DOI: http://dx.doi.org/10.12345/ius.v4i1.277;

Raharjo, Satjipto. 2000. Ilmu Hukum. Bandung: Citra aditya Bakti;

Rohman, Fatchur. "Sistem Pertanggungjawaban Pidana Korporasi”. 19 May 2016. https:// constituendum.wordpress.com/2016/05/ 19/sistem-pertanggungjawaban-pidanakorporasi, diakses on February 19, 2018;
Saputra, Ferdy Ari. "Dampak Program Pemberantasan IUU Fishing Terhadap Hubungan Bilateral Indonesia-China”. eJournal Ilmu Hubungan Internasional. Vol. 4. No. 4. 2016. Pp. 1271-1284;

Satria, Hariman. "Pertanggungjawaban Pidana Korporasi dalam Tindak Pidana Sumber Daya Alam". Jurnal Mimbar Hukum. Vol. 28 No. 2 2016. Pp. 289-299. DOI: https:// doi.org/10.22146/jmh.16722;

Sirait, Timbo Mangaranap. "The Implementation of Procedural Law of Liability Enforcement of Corporate Crime In Integral Criminal Justice System". Jurnal Dinamika Hukum. Vol. 17, No. 3. 2017. Pp. 342349. DOI: http://dx.doi.org/10.20884/1. jdh.2017.17.3.769;

Situmorang, Jegesson P. "Pertanggungjawaban Pidana Korporasi dalam Menanggulangi Tindak Pidana Perikanan". Jurnal Diponegoro Law Journal. Vol. 5, No. 3, 2016. Pp. 1-17;

Supramono, Gatot. 2011. Hukum Acara Pidana dan Hukum Pidana Di Bidang Perikanan. Jakarta: Rineka Cipta;

Susanto, I.S. 1995. Kejahatan Korporasi. Semarang: Badan Penerbit Universitas Diponegoro;

Wahyuningtyas, Yuli Winiari. "Penanganan Tindak Pidana di Bidang Perikanan Berdasarkan Peraturan Perundang-Undangan Di Indonesia". Jurnal Rechtens. Vol. 6. No. 1. June 2017. Pp. 32-45;

Wibisana, Andri G. “Kejahatan Lingkungan Oleh Korporasi: Mencari Bentuk Pertanggungjawaban Korporasi dan Pemimpin/Pengurus Korporasi Untuk Kejahatan Lingkungan di Indonesia". Jurnal Hukum dan Pembangunan. Vol. 46. No. 2. 2016. Pp. 149-195. DOI: http://dx.doi.org/10.21143/jhp.vol 46.no2.74;

Yustianingtyas, Levina. "Pertanggungjawaban Pidana Korporasi dalam Tindak Pelanggaran HAM di Indonesia". Jurnal Ilmu Hukum NOVELTY. Vol. 7 No. 1 February 2016. Pp. 25-42. 